\title{
Where do babies come from?
}

\author{
William Harvey spent a lifetime searching for the earliest moments of life.
}

\section{R. V. Short}

W illiam Harvey (1578-1657) was one of the most distinguished physicians and scientists of the seventeenth century. He was trained by the great anatomist Fabricius in Padua, and, on returning to England, eventually became physician to King Charles I. He was to achieve international acclaim when, in 1628 , he published the slim volume De Motu Cordis et Sanguinis in Animalibus (On the motion of the heart and the blood in animals). This was the first accurate description of the circulation of the blood, based on acute clinical observations and experiments on live animals.

But Harvey's lifelong obsession was with the far more mysterious subject of reproduction. How was life transmitted from generation to generation? How was it conceived?

Harvey was an Aristotelian at heart, and Aristotle had a 'seed and soil' concept of reproduction, believing that the male provided the seed, which united with the menstrual blood to form an egg. Thus the egg was a product of conception, not something produced by the ovary.

Harvey used an experiment of nature to test Aristotle's views. He chose to study the generation of deer, which are strict seasonal

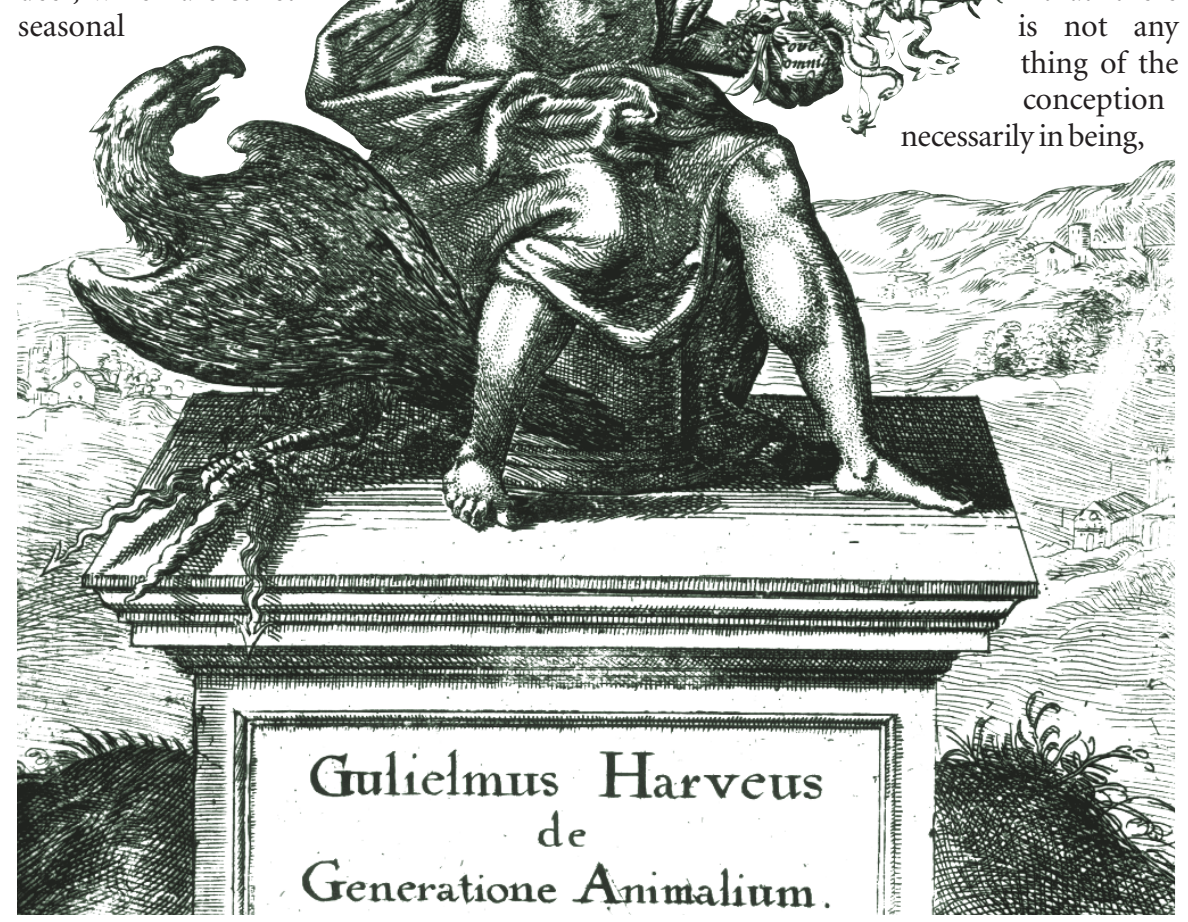

Divine rite: Zeus brandishes the all-powerful egg in Harvey's De Generatione Animalium. deer once a week in his royal forests, parks and chases, and was fascinated by Harvey's studies of generation.

During the rutting season, which starts in late September for red deer and early October for fallow deer, the stags and bucks, with hard-horn antlers and passions inflamed by high levels of testosterone, become too dangerous for the huntsman to dispatch with a thrust of his sword. In Harvey's own words: "Their lust enrages them so, that they will assault or Doggs or Men, when at other times they are shie and timorous, and suffer themselves to be chased and put to flight upon the alarme of the least barking curre that is." So, from September to December, the quarry switched to hind and doe, and Harvey could search for Aristotle's eggs in the lumen of the uterus. Imagine his confusion, therefore, when he could not find any product of conception until early November.

This forced him to conclude that "the foetus doth neither proceed from the seed of male and female emitted in coition, nor yet from any commixture of that seed, (as the Physitians will have it) nor yet out of the Menstruous blood, as Aristotle i? conceits; and - likewise that there thing of the conception . breeders. His patron, King Charles, hunted

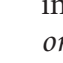

Harvey would no doubt be mystified by our disapproval of those animal experiments that had enabled him to discover the circulation of the blood, and our condemnation of the hunting of deer with hounds. But a wry smile might have crossed his lips when he read in Nature of the cloning of Dolly the sheep, showing that something in the cytoplasm of the enucleated, unfertilized egg has the ability to restore totipotency to a differentiated somatic cell nucleus. He would also be pleased to hear that it is the egg that transmits mitochondrial DNA from generation to generation, and that it is these maternally derived mitochondria that even control the motility and hence the fertility of the male's sperm. Exovo omnia indeed! R. V. Short is in the Department of Obstetrics and Gynaecology, University of Melbourne, Royal Women's Hospital, 132 Grattan Street, Melbourne, Victoria 3053, Australia. 